\title{
FACTORS LIMITING \\ THE DISTRIBUTION OF \\ THE PRAIRIE RATTLESNAKE
}

VICTOR GANNON, Dept. of Biology, University of Regina, Regina,

Saskatchewan

The prairie rattlesnake Crotalus viridis viridis is an important predator of small mammals and birds on the Great Plains of North America. According to Klauber the geographical range of this rattlesnake extends from northern Mexico to southern Canada. ${ }^{3}$

In Canada this subspecies is found in south western Saskatchewan and southern Alberta. Cook has indicated that two population segments occur in Saskatchewan, the first along the South Saskatchewan river and a second along the Frenchman river. These two segments are believed to be joined in Alberta. ${ }^{2}$

The precise reason for the restriction of the prairie rattlesnake to these areas is an interesting ecological problem. The distribution of this snake ends rather abruptly with no concomitant biotic or climatological change.

In 1976 the author began a two year study to determine possible factors which could limit the distribution of this subspecies in Canada. In the course of the study a total of 21 rattlesnake hibernacula in Saskatchewan and Alberta were visited and described. In addition the location and description of 14 hibernacula were obtained from local residents and other investigators.

The major rivers in southern Saskatchewan and Alberta can be divided into two major river systems or drainages: (1) the South Saskatchewan River drainage, including the South Saskatchewan, Red Deer, Bow and Oldman rivers, and (2) the Missouri River drainage, including the Milk and
Frenchman rivers.

All but one of the 35 hibernacul investigated were located along thes drainage systems. The exception wa located on a minor drainage betwee the Milk and South Saskatchewa rivers.

Slump blocks, meander scarp subterranean water channels and roc outcrops in these drainages suppl suitable conditions for hibernation The presence of deep fissures an subterranean cavities in thes structures makes it possible for th rattlesnakes to communally hibernat below the frost line.

In addition to the structure, th orientation of the denning site is als important. The hibernaculum usually located on a fairly steep sout facing slope. This provides maximu solar insolation as well as som protection from the prevailing wind This favorable microclimate reduce frost penetration and allows th rattlesnakes to be active a long period of time.

The area surrounding the hibe nacula showed a similar consistenc This area can be divided into tw separate habitat zones: (1) the rivi valley complex, and (2) the surrou ding prairie.

The topography and vegetation the river valley complex tends to va with the location. However, in generi they consist of a series of steep erode 
Pendlebury have reached similar conclusions. ${ }^{245}$

\section{Geographical Isolation and Speciation}

In the New World there are 41 species and 76 subspecies in the family Crotalidae. The state of Texas alone has 15 species in this family. The reason for this great species diversity is a special result of their ecology.

Each species or subspecies is uniquely adapted to its local habitat. In a number of instances more than one species may occupy the same area but little competition occurs because of differences in habitat preference, food supply or activity.

Speciation, i.e. the creation of new species and subspecies, is thought to be the result of reproductive isolation of two populations of the same species. If some barrier such as geography prevents the interbreeding of two populations, a new species may develop. Each isolated population adapts independently to its own local environment. This results in morphological changes such as color and size as well as changes in behavior such as reproductive behavior and daily activity.

Rattlesnake populations are ideally suited for this type of speciation for a number of reasons. Communal hibernacula are discrete and often quite widely separated. It is therefore unlikely that much interbreeding occurs between denning populations. For example, Brown and Parker and others have shown the high fidelity of adult snakes to a particular denning site. 'In addition, the size and means of locomotion of the animal severely restricts the amount of movement possible between dens. These conditions would certainly seem to restrict the amount of interbreeding and thus gene flow between denning populations.
Klauber has divided Crotalus viridi into nine subspecies based on mo phological criteria such a squamation, coloration, size and bod proportion. ${ }^{3}$

The distribtuion of the prairi rattlesnake in Saskatchewan an Alberta presents an interestin problem. The population segment along the South Saskatchewan rive drainage and Missouri river drainag may be somewhat isolated from on another.

The level of gene flow betwee these population segments or for tha matter within each segment is ur certain. Taxonomic and behavie studies are required to clarify th situation.

\section{Acknowledgements}

I would like to thank Mr. P. Kowatc for his assistance in this work and $h$ generous hospitality during our stay the Estuary area. Special thanks goe to Dr. D. M. Secoy for advice an finanacial assistance. Invaluable aid field work was given to me by Pamel Gannon, Tom Vincent and Alle Ireland. Finally I would like to than Parks Canada for financial aid in th research.

'BROWN, W. S. and W. S. PARKER, 197 Movement ecology of Coluber co strictor near communal hibernacul Copeia 1976(2):225-242.

${ }^{2}$ COOK, F. R. 1965. Additions to the knom range of some amphibians and reptiles Saskatchewan. Can. Field-Nat. 79(2):11 120.

${ }^{3}$ KLAUBER, L. M. 1972. Rattlesnakes. Uni of California Press, Los Angeles. 2 vol pp. 1-1533.

${ }^{4}$ MCKENNA, M. G. and G. Allard. 197 Rattlesnake Research. North Dako Outdoors 1976:11-13.

${ }^{5}$ PENDLEBURY, G. B. 1977. Distribution ar abundance of the prairie rattlesnak Crotalus viridis viridis in Canada. Ca Field-Nat. 91(2):122-129. 